ISSN: 2146-3042

DOI: $10.25095 /$ mufad.465721

\title{
Benford Analizi İle Muhasebe Denetimi: Kamu Hastaneleri Üzerine Bir Uygulama
}

\author{
Mehmet Akif ÖNCÜ* \\ Rahmi YÜCEL ${ }^{* *}$ \\ Onur ÖZEVİN***
}

\begin{abstract}
ÖZET
Muhasebe bilgi sisteminin ürettiği bilgilerin doğru ve tarafslz olması bilgi kullanıcıların doğru karar vermelerinde etkilidir. Finansal tabloları gerçekte olduğundan farklı gösterecek bir işlem, karar alıcıları zarara uğratabilir. Muhasebede hile denetiminin birçok yolu olmakla beraber, her türlüsü maliyet ve zaman gerektirir. Son yıllarda yaygınlaşan dijital analiz teknikleri denetim sürecinin kapsamının genişletilmesi, kolaylaştırllması ve hızlandırılması yönünde olanaklar sağlamaktadır. Bu tekniklerden biri olan Benford Analizi, kolaylığı ve düşük maliyetli oluşuyla öne çıkmaktadır. Benford analizi, rastgele oluşmuşs sayılardaki rakamların, her basamakta görülme sıklı̆̆ının farklı olduğunu ifade eden Benford Kanunu temeline dayanmaktadır. Benford Kanunu'na göre rastsal oluşmuş bir veri kümesinde beklenen değerlere uymayan dağılımlar hile sinyali olarak değerlendirilebilir. Çalışmada Türkiye'de faaliyet gösteren iki kamu hastanesinin gelir ve gider hesap verilerine Benford Analizi kapsaminda, 1.Basamak, 2.Basamak ve İlk İki Basamak testleri uygulanmiş, kritik değerlere göre uyum dereceleri belirlenmiştir. Sonuçta, analiz edilen iki hastaneden birinin verilerinin Benford Kanunu ile uyum sağladı̆̆l, diğer hastane verilerinin ise uyumsuzluk gösterdiği saptanmıştır.
\end{abstract} Denetimi.

Anahtar Kelimeler: Benford Kanunu, Dijital Analiz, Bilgisayar Destekli Denetim Teknikleri, Hile

JEL Sinıflandırması: M42, M41

\section{Audit With Benford Analysis: An Application On Public Hospitals}

\section{ABSTRACT}

The accounting process is the primary source of information for all information users, directly affecting the economic and social environment. Along with many ways to control fraud in accounting, all sorts require cost and time. Digital analysis techniques, which have become widespread in recent years, provide opportunities to expand, facilitate and accelerate the scope of the audit process. One of these techniques, Benford's analysis is based on the Benford Law, which states that the racial numbers in random numbers are often unfamiliar to each other. According to the Benford Law, distributions that do not fit the expected values in a random data set are considered fraud signals. In the study Benford Analysis was applied to various accounting accounts of two public hospitals operating in Turkey. The objective of the study is to test the compliance of the public hospitals examined comparatively with the Benford Law. In the scope of Benford Analysis, the first, second and first two step tests were applied to the selected calculator data, the actual results and expected values were compared and the compliance scores were determined according to the MAD critical values. As a result, it was determined that the data of one of the two analyzed hospitals were in compliance with the Benford Law and the other hospital data showed incompatibility.

Keywords: Benford's Law, Digital Analysis, CAATs, Fraud Detection

Jel Classification: M42, M41

\footnotetext{
* Prof.Dr. Mehmet Akif Öncü, Düzce Üniversitesi, İşletme Fakültesi, mehmetakifoncu@duzce.edu.tr

** Doç.Dr. Rahmi Yücel, Abant İzzet Baysal Üniversitesi, İktisadi ve İdari Bilimler Fakültesi,yücel_r@ibu.edu.tr

*** Dr.Öğr.Gör. Onur Özevin, Abant İzzet Baysal Üniversitesi, Gerede Meslek Yüksekokulu,

onurozevin@ibu.edu.tr
} 


\section{GíRiş}

ACFE 2016 raporuna göre, ortalama olarak işletmeler yılda gelirlerinin \%5'ini hile nedeniyle kaybetmektedirler ve hilelerin neden olduğu toplam kayıp 6,3 milyar \$ olarak saptanmıştır. \%83 ile en fazla rastlanan hile çeşidi "zimmete para geçirme" olurken, finansal tablo hilelerinin ağırlığı \%10 civarındadır. GİB 2016 raporuna göre incelenen 6.861 mükellefin tüm vergi türlerinde beyan edilen matrah 2.118.233.018 iken bulunan matrah fark1 1.273.504.628 olmuştur. Yani tüm vergi türlerinde matrah $\% 60$ eksik beyan edildiği tespit edilmiştir. $\mathrm{Bu}$ bilgiler 1 şı̆̆ında değerlendirildiğinde muhasebe denetimi için daha etkin yöntemler geliştirilmesi gerekliliğinin önemi ortaya çıkmaktadır.

Benford Kanunu'nun ilk ortaya çıkışı, Amerikalı astronom ve matematikçi Simon Newcomb'un, rakamların sayı basamaklarındaki görülme sıklığı ile ilgili, 1881 yılında American Journal of Mathematics'de yayımladığı iki sayfalık makalesine dayanır. Newcomb rakamların (0-9) basamaklarda görülme sıklığının eşit olmadığı ortaya atmış ve her rakamın, sayının farklı basamaklarında bulunma olasılığını gösteren ve bir tablo oluşturmuştur. (Newcomb, 1882;39). Buna göre bir rakamın ilk basamakta bulunma siklı̆g1 1'den 9'a gidildikçe azalmaktadır. 3. Basamakta olasılıklar birbirine çok yakın olmakta, 4. basamaktan itibaren ise fark belirsizleşmektedir. Bu kural büyük sayı kümeleri içinde doğal oluşumla ilgili işaretler vermektedir (Newcomb, 1882;40). Newcomb sifirdan farklı anlamlı bir rakamın, sayının ilk basamağında olma olasılığını aşağıdaki şekilde ifade etmiştir: (Hill, 1998;358)

$$
\text { Olasılık (ilk basamaktaki rakam }=\mathrm{d})=\log 10(1+1 / \mathrm{d}),(\mathrm{d}=1,2, \ldots, 9)
$$

Newcomb'un modeli 57 y1l boyunca Frank Benford isimli fizikçinin benzer gözlemler yapmasına kadar neredeyse unutulmuştur. Benford 1938 yılında Proceedings of The American Philosophical Society'de yayımlanan "The Law of Anamolous Number" başlıklı makalesinde 20.229 farklı veri setinden elde ettiği dağılım sonuçlarının ortalamasını alarak her rakamın sayı basamağında bulunma sıklığını tablo üzerinde göstermiştir. Bu gözlemlerini; nehir uzunlukları, nüfus sayıları, gazete tirajları, futbol lig istatistikleri, atom ağırlıkları, ölüm oranları gibi coğrafi bilimsel ve demografik çeşitli kaynaklardan topladığı veriler üzerinden yapmıştır (Benford, 1937;553). Grafik 1, bu bulgulara göre Benford'un sonuçlarını göstermektedir.

Grafik 1: Rakamların Birinci Basamakta Bulunma Sıklıkları

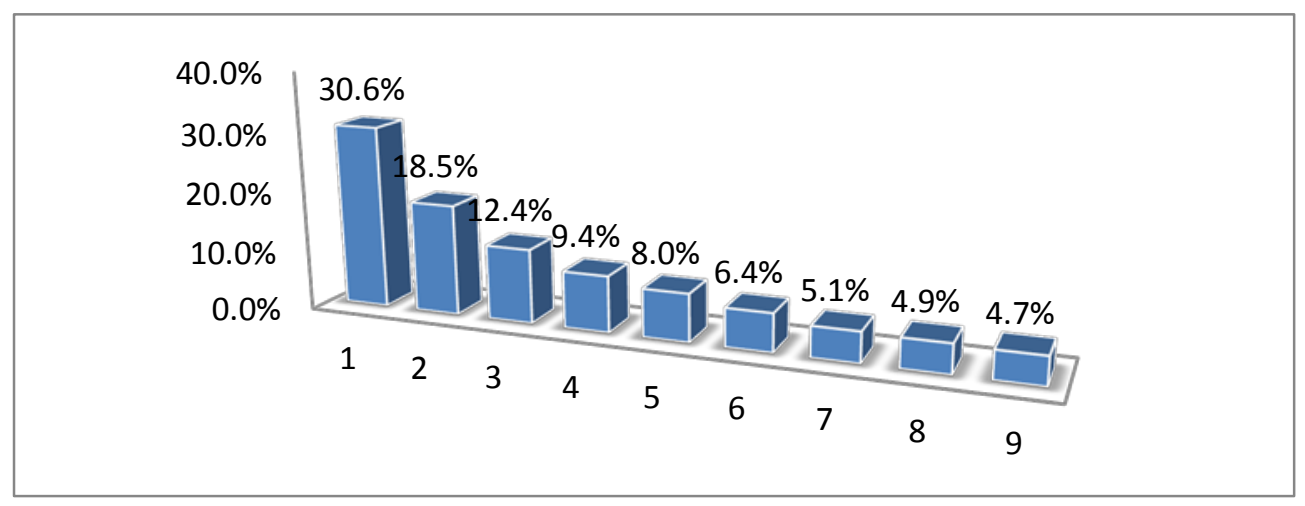

Kaynak : Benford, 1937;553 


$$
\begin{array}{ll}
\text { İlk basamak Formülü } & \text { : Olasılık }\left(\mathrm{D}_{1}=\mathrm{d}_{1}\right)=\log \left(1+\left(1 / \mathrm{d}_{1}\right)\right) ; \mathrm{d}_{1}=(1,2,3 \ldots 9) \\
\text { İkinci Basamak Formülü } & \text { : Olasıl1k }\left(\mathrm{D}_{2}=\mathrm{d}_{2}\right)=\log \left(1\left(1 / \mathrm{d}_{1} \mathrm{~d}_{2}\right)\right) ; \mathrm{d}_{2}(1,2,3 \ldots 0) \\
\text { İlk iki Basamak Formülü } \quad \text { Olasılık }\left(\mathrm{D}_{1} \mathrm{D}_{2}=\mathrm{d}_{1} \mathrm{~d}_{2}\right)=\log \left(1+\left(1 / \mathrm{d}_{1} \mathrm{~d}_{2}\right)\right) \\
\text { Olasılık }\left(\mathrm{D}_{2}=\mathrm{d}_{2} \mid \mathrm{D}_{1}=\mathrm{d}_{1}\right)=\log \left(1+\left(1 / \mathrm{d}_{1} \mathrm{~d}_{2}\right)\right) / \log (1+(1 / \mathrm{d} 1)) \\
\mathrm{D}_{1} \text { :Sayının ilk basamağ1 } \\
\mathrm{D}_{2} \text { :Sayının ikinci basamağ1 (Durtschi, 2004;19) }
\end{array}
$$

Atlanta Georgia Teknoloji Enstitüsü Matematik Profesörü Ted Hill, 1996 yılında Statistic Science'da yayımlanan makalesinde, Benford Kanununu matematiksel olarak kuvvetlendiren verilerin değişmezliği ölçüsünü kullanmış, yasada sayıların ifade edildikleri birimden bağımsız olduklarını göstermiştir (Hill, 1998;361). Newcomb’un denklemini basamak kombinasyonlarını içerecek şekilde genişletmiştir:

$\mathrm{P}\left(\mathrm{d}_{1}, \mathrm{~d}_{2}, \mathrm{~d}_{3} \ldots\right)=\log 10[1+(\mathrm{d} 1, \mathrm{~d} 2, \mathrm{~d} 3 \ldots . \mathrm{dk})-1] \quad$ Örneğin, bir sayının 314 ile başlama olasılığ $\log 10(1+(314)-1)=0,0014$ 'tür (Hill, 1999;29).

İnsanların tesadüfi olarak sayı üretemeyeceği esasına dayanan Benford Kanunu için Hill'in denemesi örnek olarak gösterilebilir. Olasılık teorisi dersinde 2 gruptan birine 200 denemede yazı tura sonuçlarını yazmaları istenir. Diğer guruba ise bu 200 atışın tahmini sonuçlarını yazmaları istenir. Pratikte $6 \mathrm{kez}$ peş peşe aynı yüz gelme durumu sıklıkla meydana gelmesine rağmen tahmin gurubu sonuçlarında hiç rastlanmamıştır (Hill, 1998;362). Başka bir denemede 742 öğrencisine rastgele 6 basamaklı sayılar oluşturmalarını söylemiş, oluşan sayıların Benford Kanunuyla az uyumlu ya da uyumsuz olduğu tespit edilmiştir (Nigrini ve Mittermaier, 1997;56).

Varian (1979) ilk kez Benford kanununun sosyal bilimlerde verilerin geçerlilik ve güvenirliğini test etmede kullanılabileceğini önermiş, ardından yasanın ilk muhasebe uygulaması Carslaw tarafından yapılmıştır (Durtschi, 2004;21). Çalışmada şirket gelirlerinin yöneticiler tarafından psikolojik sınırların üzerine yuvarlandığı sonucuna, verilerin Benford dağılımına uyumsuz olmasından yola çıkılarak ulaşılmıştır (Drake, 2004;21). Thomas (1989) net kar verileri üzerine yaptığı uygulamada ikinci basamakta 0 rakamının daha fazla bulunduğunu, zarar tutarlarında ise tersi durum olduğunu fark etmiş, ayrıca hisse başına kazançta 5 rakamının beklenenden fazla 9 rakamının ise az olduğunu gözlemlemiştir. Bunun kar rakamlarının yukarı zarar rakamlarının aşağı doğru yuvarlanmasından kaynaklandığını tespit etmiştir (Thomas, 1989;787).

Rakamların ortaya çıkış sıklıkları Benford Kanunu ile dikkate değer bir uyumsuzluk gösteriyorsa, bu sayıların doğal yolla oluşmadığına işaret olabilir. Bu durum muhasebe verilerinde karşımıza çıkarsa, hile olasılığı akla gelecektir. Bu varsayımdan hareketle Mark J. Nigrini, Benford kanununun muhasebe hilelerinin ortaya çıkarılmasında bir yöntem olarak kullanılabileceğini düşünmüştür (Nigrini, 2001;2). Satışlardan giderlere kadar birçok muhasebe verisinin, Benford Kanununa uyum gösterdiğini ve bu verilerdeki yasadan sapmaların, istatistiki testlerle ortaya çıkarılabileceğini göstermiştir. Verilerin Benford 
Kanunu’na uygunluk testleriyle ölçülmesinde, muhasebenin normal verileri ve hileli verileri arasında büyük farklar ortaya çıkmıştır. Nigrini, bu modeli kullanarak New York Brooklyn Vergi Servisinde, New York'taki yedi şirketin muhasebe hilelerini ortaya çıkarmış, bunu takiben Amerika'nın çeşitli eyaletlerinin vergi servisleri bu modeli kullanmaya başlamıştır. (Alagöz ve Ay, 2001:5) Daha sonra denetim alanında önde gelen yazılım firmalarınca bu model veri analiz paketlerine eklenmiş ve Dijital Analiz adıyla dünyanın çeşitli yerlerinde kullanımı yaygınlaşmıştır.

Basitçe Benford kanunu rakamların sayı basamaklarında beklenen bulunma sıklığını ifade eder. Yapılan çalışmalarda Benford Kanunu'nun, doğal yolla oluşmuş; borsa kapanış verilerinden gazete tirajlarına, ülkelerin GSMH değerlerinden, nehirlerin yüzölçümlerine, sera gazı salınım değerlerinden oy pusulası sayımına kadar çok farklı alanlardaki veri setlerinde geçerli olduğu ispatlanmıştır. Dolayısıyla beklenen sıklıktan farklı bir durum oluşması rakamların insan müdahalesinden etkilendiğine işaret edeceğinden bu araç muhasebe denetiminde oldukça kullanışı kabul edilmiştir. Bu teoriye göre Benford Kanunu vergi beyanlarında anormalliği ve planlanmamış kaçağı tespitte etkilidir (Erdoğan,2014:96). Modelin oldukça kolay ve ucuz olması muhasebe denetimi alanında hile ve hataların tespitinde kullanımını yaygınlaştırmıştır.

Literatürde, Benford analizi sonucunda beklenen ile gerçekleşen basamak dağılımları arasındaki sapmalar, anlamlılık testleri ve/veya kritik değerlerle karşılaştırılarak yorumlanmaktadır. Çalışmada Benford analizi bir kıyaslama ölçütü olarak kullanılarak, muhasebe verilerinde hile tespitinde farklı şekilde kullanımı araştırılmıştır.

\section{LITERATÜR}

Durtschi (2004) 2004 yılında yarım yüzyılda Benford Kanunu ile ilgili 150 den fazla çalışma yayımlandığını ifade etmişken, Nigrini (2012) 2012 yılında Benford ile ilgili yayımlanmış 750 makale bulunduğunu bu sayısının 2015 sonunda 1500' yaklaşacağını tahmin etmiştir (www.benfordonline.net). Özellikle muhasebe denetimi alanındaki çalışmalardan bazılarına aşağıda değinilmiştir.

Akkaş (2007) çalışmasında bir şirketin 12.194 adetlik Ticari Mallar hesabı kayıtlarını dijital analize tabi tutmuştur. Sonuçların Benford Kanunuyla uyumsuzluk gösterdiğini ifade etmiştir. Kocameşe (2006) çalışmasında bir firmanın 37.956 adet satış faturasına dijital analiz uygulamış; ilk rakam testi sonucunun Benford Kanunuyla uyumlu çıktığını, ikinci rakam testinde bazı uyumsuzluklar bulunduğunu ifade etmiştir. Boztepe (2013) çalışmasında bir belediyeye ait gelir ve gider rakamlarının Benford Kanununa uyumunu test etmiştir. 1511 gelir rakamından oluşan veri setinin test sonucu uyumlu çıkmış, 703 adet gider rakamından oluşan veri setinde ise uyumsuzluklar tespit edilmiştir. Uzuner (2014) makalesinde Borsa İstanbul'da işlem gören bankaların konsolide bilançolarının Benford Kanununa uygunluğu incelemiştir. İlgili bankaların bilançolarında yer alan hesapların tutarlarındaki ilk rakamların dağılımının büyük bir çoğunluğunun Benford Kanununu izlediği, bazı hesapların tutarlarındaki ilk rakamların dağılımının ise, farklılık gösterdiği saptanmıştır. Demir (2014) bir şirketin pazarlama satış dağıtım giderlerinin ilk, ikinci ve ilk iki basamak dijital analizini yapmış, sonuçta Benford Kanunu'na göre beklenen değerlerden bazı uyumsuzluklar tespit etmiştir. Özdemir (2014) bir şirkete ait 185.083 adet satış faturasını TL ve USD karşılıklarıyla ayrı ayrı dijital analize tabi turmuş. Birinci basamak ve ikinci basamak sonuçlarının her iki 
para biriminde de Benford ile uyumlu olduğunu ifade etmiştir. Yanık ve Samancı (2013) bir kamu işletmesine ait "Genel Yönetim Giderleri" hesabının muavinine uyguladıkları Benford testinde sonuçları beklenen ile uyumlu olduğunu ifade etmişlerdir. Özer ve Babacan (2013) çalışmalarında Türkiye'de faaliyet gösteren bankaların bilançolarının nazım hesaplarında Benford kanunu ile hile belirtisi araştırmışlar, sonuç olarak 2000-2010 yılları arasında bir uyumsuzluğa rastlanmazken, 1999 yılında hile ve manipülasyon belirtileri bulmuşlardır. Çalış vd.(2014) sağlık sektöründe faaliyet gösteren bir firmanın satın alma verilerine dijital analiz yöntemlerinden Benford Kanunu uygulamış, analizin sonuçlarının yüksek hile olasılığını işaret ettiğini ifade etmişlerdir.

Carslaw (1988) 220 şirketin gelir rakamlarının Benford Kanunuyla uyumlarını test ettiği çalışma sonucunda, ikinci basamakta 0 sayısının beklenenden fazla 9 sayısının ise beklenenden az bulunduğunu tespit etmiştir. Quick ve Woltz (2005) Almanya'da bulunan şirketlerin 1994-1998 y1llarına ait, 1820 adet finansal tablo verisi üzerinden Benford testlerini uygulamış, sonuçlarda anormalliğe rastlanmadığını ifade etmişlerdir. Johnson (2013) Benford Kanununu ABD’nin 50 eyaletine ait seçilmiş bilanço kalemlerine uygulamışlardır. ACL yazılımı yardımıyla 3 yıllık finansal tablo verilerine uygulanması sonucu uyumlu ve uyumsuz kalemler tespit edilmiştir. Nigrini ve Mittermaier yasayı 1995 yılında Amerika Başkanı Clinton'un vergi ödemelerine uygulamış, 13 yılık vergi ödemelerinin Benford dağılımını izlediği ortaya çıkmıştır. Dünya üzerinde birçok şirket, denetim firması ve vergi idaresi Benford Kanunu'nu kullanmaktadır. Dünyanın en büyük denetim firmaları Benford Kanunu'nu yazılım olarak kullanmaktadır (Nigrini, 2012:xvi).

Benford Kanunu temelli dijital analizin önemli bir kuralı veri setinin neden Benford Kanununa uyması gerektiğinin belirlenmesidir. Çalışmamız aynı kurumun birden fazla işletmesinin verileri üzerinden karşılaştırmalı olarak analiz sonuçlarını göstereceğinden, uyumsuzluk derecesinin anlamı daha net okunabilecektir.

\section{BENFORD ANALIZİ}

Benford Kanununun kullanımında beş önemli test bulunmaktadır. Bunlar; İlk basamak testi, İkinci Basamak Testi, İlk İki Basamak Testi, İlk Üç Basamak Testi ve Son İki Basamak testleridir. İlk ve İkinci basamak testleri verilerin seçiminde yüksek seviyeli uygunluk testleridir. İlk iki Basamak ve İlk Üç Basamak testleri denetim hedeflerinin seçiminde kullanılabilir. Son iki basamak testi türetilmiş rakamları tespit etmede güçlü bir testtir, yuvarlamalarını tespit etmekte kullanılabilir. Veri setlerinin Benford ile zayıf uyumu, veri ile ilgili bir anormalliğin sinyali olabilir. Dolayısıyla elinde 4 veri seti bulunan bir araştırmacı, 3 set Benford ile uyumlu iken 1 set uyumsuzluk gösteriyorsa, stratejisi uyumsuz verilere odaklanmak olmalıdır çünkü hile riski yüksektir (Nigrini, 2012:74). Benford Kanununa uygunluğu test edilecek veri setlerinin aşağıdaki şartları sağlamaları gerekmektedir (Quick, 2005:1290).

- Veri kümesi, benzer olguların büyüklügünü tanımlamalıdır; Veriler aynı cinsten olayları ifade etmelidir. Örneği tümü şehir nüfusları veya tümü yıllık satışlar.

- Veri kümesindeki değerlerin alt veya üst limitinin olmaması gerekmektedir. Maksimum ve minimum sınırlar dağılımı bozmaktadır. 
- Veri kümesindeki değerlerin atanmış sayılar olmaması gerekmektedir. Sayıların doğal yoldan rastsal oluşmuş olması kanunun ana şartlarından biridir (Akbaş, 2007;196).

Benford Kanunu en iyi şekilde büyük veri kümelerine uygulanabilmektedir. Veri kümesinin büyüklügü arttıkça analizin verimliliği de artmaktadır(Drake ve Nigrini :132). Araştırmalar 4 yada daha çok basamaklı sayıların Benford Kanunu ile uyum düzeyinin yüksek olduğunu göstermiştir (Çakır, 2004; 77).

Benford'un Aşamaları (Erdoğan, 2014:84)

1.Ana kütle / Veri seti belirlenir.

2.Muhtemel eğilimler (maksimum-minimum değerler) göz önünde bulundurulur.

3.Herhangi bir anormalliğin oluştuğu ilgili alanlar belirlenir.

4. Yazılım programına veriler girilir.

5.Dijital analiz yapılır. (ilk basamak, ikinci basamak, ilk iki basamak vd.)

6.Beklenen değerlerle sonuçlar karşılaştırılır.

7.Dikkat çekici sapmalar belirlenir.

8.İstatistiki analizler ile uyumluluk test edilir.

Sonuçların uyumunu test etmek için Ki-Kare, Z-testi ve Kolmogorov Simirnov testleri uygulanabilir. Nigrini'ye göre bu testler aşırı güç probleminden ötürü yanlış sonuçlar verebilir. Veri kümesinin büyüklüğünden dolayı normal kabul edilmesi gereken bir sapma bu testlerde hile sinyali olarak görülebilir. Bu yüzden veri sayısını hesaba katmayan Mutlak ortalama sapma (MAD) testi, diğer istatistiki testlere tercih edilmektedir. Benford Kanunu ile uyumluluğu test edilirken çıkan sonuçla beklenen değer arasındaki sapma (Ortalama Mutlak Sapma - MAD) şu şekilde hesaplanmaktadır.

$$
=\frac{\sum_{i=1}^{K}|A P-E P|}{K}
$$

AP; gerçekleşen dağılımları, EP Benford Dağılımlarını göstermektedir. K ise ilk basamak testi için 9, ilk iki basamak testi için 90 değerini alır. Sonuçlar Tablo 1'deki sınırlara göre değerlendirilir. (Nigrini,2011;160) 
Tablo 1: Benford Kanunu Uyum Sinırları

\begin{tabular}{|l|l|l|l|}
\hline İlk Basamak & İkinci Basamak & İlk İki Basamak & Sonuç \\
\hline $0,000-0,006$ & $0,000-0,008$ & $0,0000-0,0012$ & Yakın Uyumlu \\
\hline $0,006-0,012$ & $0,008-0,010$ & $0,0012-0,0018$ & Kabul Edilebilir Uyumlu \\
\hline $0,012-0,015$ & $0,010-0,012$ & $0,0018-0,0022$ & Marjinal Kabul Ed. Uyumlu \\
\hline$>0,015$ & $>0,012$ & $>0,0022$ & Uyumsuz \\
\hline
\end{tabular}

Kaynak: Nigrini, 2011;160

\section{VERİ VE YÖNTEM}

Çalışmada Türkiye'de aynı ilde faaliyet gösteren 2 kamu hastanesinin 2015 yılı muhasebe hesapları Benford analizine tabi tutulmuştur. Analiz edilen veriler; 800 Bütçe Gelirleri Hesabı ve 830 Bütçe Giderleri Hesabı muavin defter kayıtlarından oluşmaktadır. Hesap verilerine Benford analizi kapsamında; İlk Basamak, İkinci Basamak ve ilk iki basamak testleri yapılmıştır. Beklenen değerler ile gerçekleşen değerler arasındaki sapma teoride MAD değerleri olarak verilmiş kritik değerler ile karşılaştırılmıştır. Uyumsuz veriler hile şüphesi olarak kabul edilip, ayrıntılı denetim için odaklanılması gereken verilerin belirlenmesini sağlayacaktır. Hastanelerin gerçek isimleri gizli tutulmuş, çalışmada A ve B olarak isimlendirilmişlerdir.

Analizde Excel tabanlı ActiveData programı kullanılmıştır. Programdan rakamların basamaklarda bulunma sıklığını hesaplayıp, Benford yasasınca beklenen dağılım oranları ile karşılaştırmaya ve sapmaların istatistiki testlerle ölçülmesinde faydalanılmıştır.

\section{BULGULAR}

Bu bölümde çalışmaya konu A ve B olarak isimlendirilen iki kamu hastanesine ait 800 ve 830 nolu hesaplarına Benford analizi uygulanmıştır. Uygulama hesaplar bazında, önce tüm testler 800 Bütçe Gelirleri hesabına, sonra 830 bütçe gelirleri hesabına uygulanmıştır. Karş1laştırmanın kolay yapılabilmesi için A ve B hastanesinin her test sonucu art arda, grafik ve tablolar ile verilmiştir. Grafiklerde sapmanın kabul edilebileceği alt ve üst sınırlar oranlarıyla birlikte gösterilmiştir.

\subsection{Bütçe Gelirleri Hesabı}

Çalışmaya konu hastanelerin 800 Bütçe gelirleri hesabı testleri bu bölümde yapılmıştır. Veri sayıları hastaneye göre değişmekle birlikte grafiklerin altında belirtilmiştir.

\subsubsection{Birinci Basamak Testi}

A Hastanesi, 800 nolu hesap muavini 3251 adet veriden oluşmaktadır. Verilerin 262 adedi 10'dan küçük olduğundan veri setinden çıkarılmıştır. Grafik 2'de A Hastanesinin 800 bütçe gelirleri hesap muavini Birinci Basamak testi sonuçlarını göstermektedir. Gerçekleşen dağılımların Benford dağılımlarına yakın izlediği görülmektedir. MAD değeri 0,00799 olarak hesaplanmıştır. Uyum tablosuyla karşılaştırıldığında veri setinin kabul edilebilir uyumlu çıktığı görülmektedir. 
Grafik 2: A Hastanesi 800 Hesabı 1.Basamak Testi Sonuçları

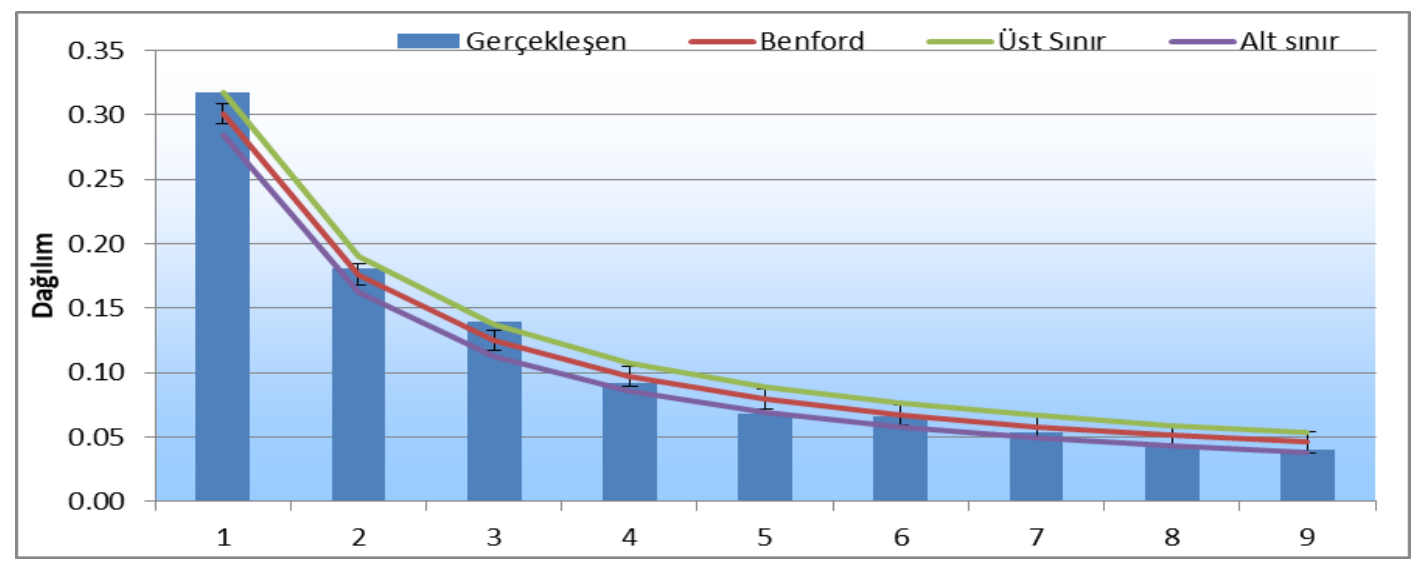

\begin{tabular}{|r|r|r|r|r|r|r|r|}
\hline \multicolumn{1}{|l|}{} & \multicolumn{1}{l|}{ Adet } & \multicolumn{1}{l}{ A } & \multicolumn{1}{l|}{ Benford } & \multicolumn{1}{l|}{ Fark } & \multicolumn{1}{l|}{ Üst Sınır } & \multicolumn{1}{l|}{ Alt sınır } & Z Değeri \\
\hline$\underline{1}$ & 950 & 0,318 & 0,301 & 0,017 & 0,318 & 0,284 & 1,983 \\
\hline$\underline{2}$ & 540 & 0,181 & 0,176 & 0,005 & 0,190 & 0,162 & 0,632 \\
\hline$\underline{3}$ & 417 & 0,140 & 0,125 & 0,015 & 0,137 & 0,113 & 2,382 \\
\hline$\underline{4}$ & 275 & 0,092 & 0,097 & 0,005 & 0,108 & 0,086 & 0,876 \\
\hline$\underline{5}$ & 202 & 0,068 & 0,079 & 0,012 & 0,089 & 0,069 & 2,315 \\
\hline$\underline{6}$ & 196 & 0,066 & 0,067 & 0,001 & 0,076 & 0,058 & 0,264 \\
\hline$\underline{7}$ & 161 & 0,054 & 0,058 & 0,004 & 0,067 & 0,049 & 0,926 \\
\hline$\underline{8}$ & 129 & 0,043 & 0,051 & 0,008 & 0,059 & 0,043 & 1,942 \\
\hline$\underline{9}$ & 119 & 0,040 & 0,046 & 0,006 & 0,053 & 0,038 & 1,512 \\
\hline $\mathrm{N}$ & 2.989 & & MAD & $\mathbf{0 , 0 0 8}$ & & & \\
\hline
\end{tabular}

B Hastanesinin 800 nolu hesap muavini 1024 veriden oluşmakta, analize dahil 10'dan büyük veri sayısı 862 'dir. Grafik 3'te gösterilen birinci basamak testi sonuçlarına göre 1,3, 5 ve 8 sayılarında sapmalar dikkat çekmektedir. 0,022 olarak hesaplanan MAD değeri uyumsuzluk seviyesindedir.

Grafik 3: B Hastanesi 800 Hesabı 1.Basamak Testi Sonuçları

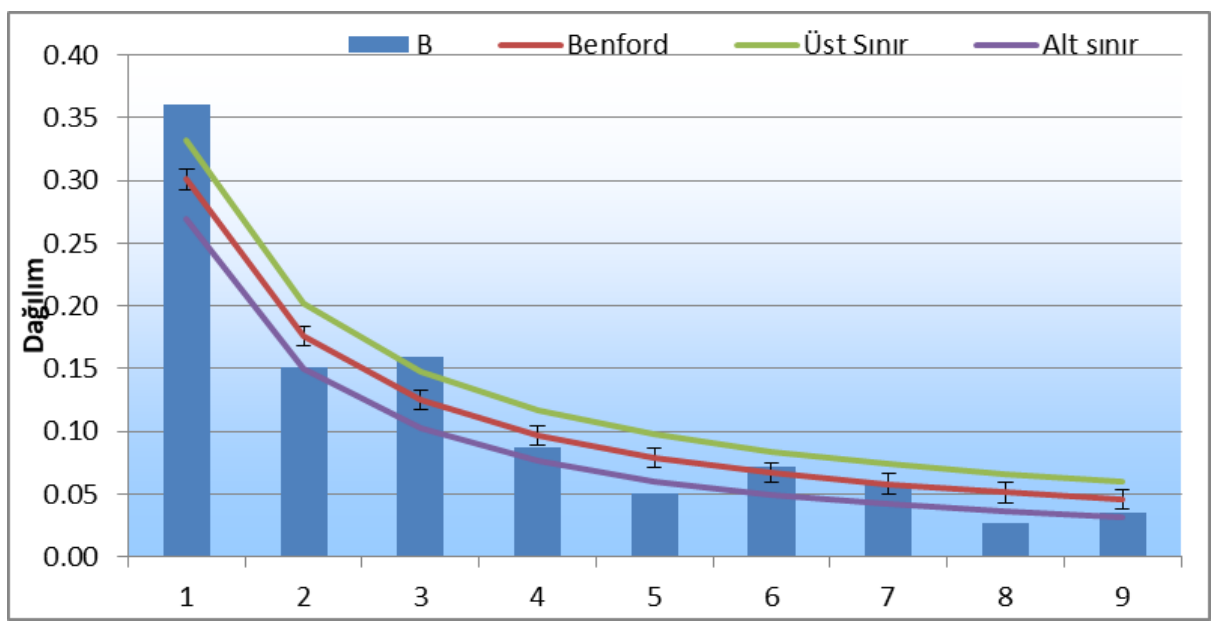




\begin{tabular}{|r|r|r|r|r|r|r|r|}
\hline \multicolumn{1}{|l|}{ 1.Basamak } & \multicolumn{1}{l|}{ Adet } & \multicolumn{1}{l|}{ B } & \multicolumn{1}{l|}{ Benford } & \multicolumn{1}{l|}{ Fark } & \multicolumn{1}{c|}{ Üst Sınır } & \multicolumn{1}{c|}{ Alt sınır } & \multicolumn{1}{l|}{ Z Değeri } \\
\hline$\underline{1}$ & 311 & 0,361 & 0,301 & 0,060 & 0,332 & 0,270 & 3,788 \\
\hline$\underline{2}$ & 130 & 0,151 & 0,176 & 0,025 & 0,202 & 0,150 & 1,904 \\
\hline$\underline{3}$ & 137 & 0,159 & 0,125 & 0,034 & 0,148 & 0,102 & 2,967 \\
\hline$\underline{4}$ & 75 & 0,087 & 0,097 & 0,010 & 0,117 & 0,077 & 0,925 \\
\hline$\underline{5}$ & 44 & 0,051 & 0,079 & 0,028 & 0,098 & 0,061 & 2,996 \\
\hline$\underline{6}$ & 62 & 0,072 & 0,067 & 0,005 & 0,084 & 0,050 & 0,517 \\
\hline$\underline{7}$ & 50 & 0,058 & 0,058 & 0,000 & 0,074 & 0,042 & $-0,071$ \\
\hline$\underline{8}$ & 23 & 0,027 & 0,051 & 0,024 & 0,066 & 0,036 & 3,184 \\
\hline$\underline{9}$ & 30 & 0,035 & 0,046 & 0,011 & 0,060 & 0,031 & 1,458 \\
\hline $\mathrm{N}$ & 862 & & MAD & $\mathbf{0 , 0 2 2}$ & & & \\
\hline
\end{tabular}

\subsection{2. İkinci Basamak Testi}

A Hastanesinin 800 hesabı ikinci basamak testi sonuçları grafik 4'te gösterilmiştir. Buna göre 0 rakamı beklenenden çok daha fazla gerçekleşmiştir. 0, 3, 7 ve 9 rakamlarının görülme sıklıklarındaki sapmalar dikkat çekicidir. MAD değeri 0,015 olarak hesaplanmış, kritik değerle tablosuna göre uyumsuz çıkmıştır.

Grafik 4: A Hastanesi 800 Hesabı 2.Basamak Testi Sonuçları

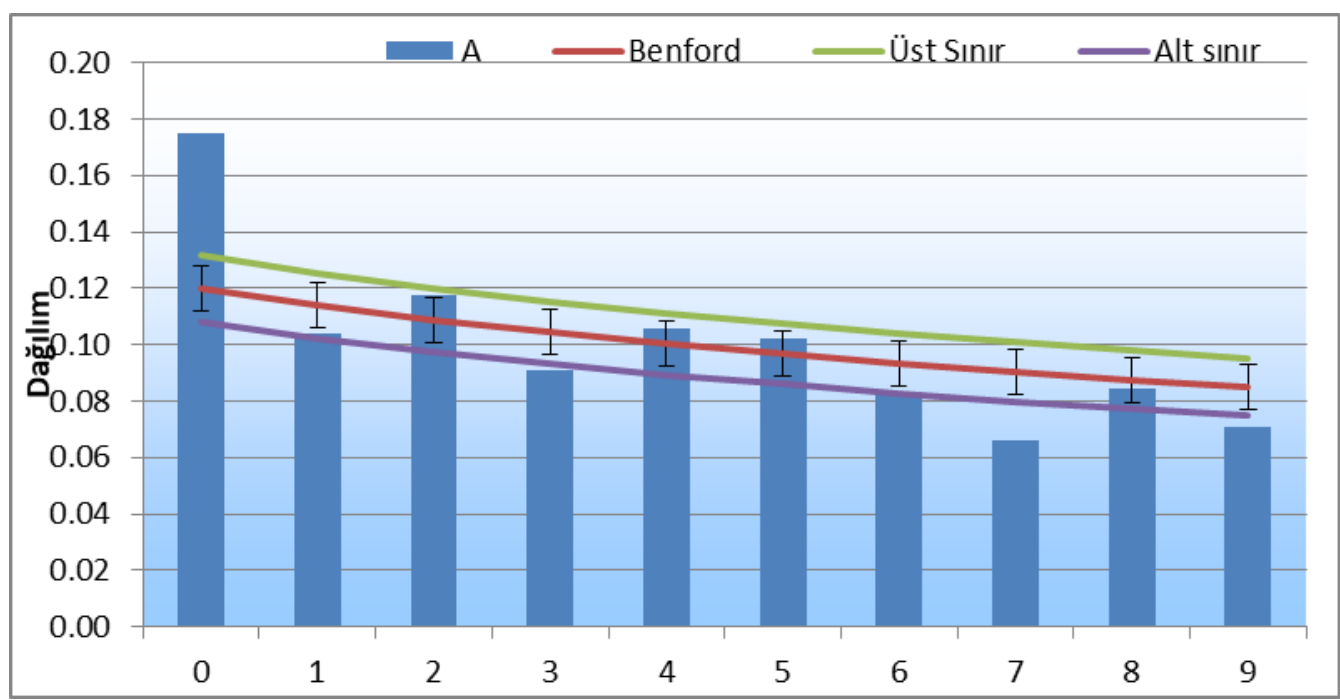

\begin{tabular}{|r|r|r|r|r|r|r|r|}
\hline 2.Basamak & \multicolumn{1}{l|}{ Adet } & \multicolumn{1}{l|}{ A } & \multicolumn{1}{l|}{ Benford } & \multicolumn{1}{l|}{ Fark } & \multicolumn{1}{l|}{ Üst Sınır } & \multicolumn{1}{c|}{ Alt sınır } & Z Değeri \\
\hline$\underline{0}$ & 523 & 0,175 & 0,120 & 0,055 & 0,131 & 0,108 & 9,285 \\
\hline$\underline{1}$ & 310 & 0,104 & 0,114 & 0,010 & 0,125 & 0,102 & 1,723 \\
\hline$\underline{2}$ & 352 & 0,118 & 0,109 & 0,009 & 0,120 & 0,097 & 1,541 \\
\hline$\underline{3}$ & 272 & 0,091 & 0,104 & 0,013 & 0,115 & 0,093 & 2,354 \\
\hline$\underline{4}$ & 316 & 0,106 & 0,100 & 0,005 & 0,111 & 0,089 & 0,955 \\
\hline$\underline{5}$ & 306 & 0,102 & 0,097 & 0,006 & 0,107 & 0,086 & 1,023 \\
\hline
\end{tabular}




\begin{tabular}{|r|r|r|r|r|r|r|r|}
\hline$\underline{6}$ & 249 & 0,083 & 0,093 & 0,010 & 0,104 & 0,083 & 1,861 \\
\hline$\underline{7}$ & 197 & 0,066 & 0,090 & 0,024 & 0,101 & 0,080 & 4,630 \\
\hline$\underline{8}$ & 252 & 0,084 & 0,088 & 0,003 & 0,098 & 0,077 & 0,598 \\
\hline$\underline{9}$ & 212 & 0,071 & 0,085 & 0,014 & 0,095 & 0,075 & 2,726 \\
\hline $\mathrm{N}$ & 2.989 & & MAD & $\mathbf{0 , 0 1 5}$ & & & \\
\hline
\end{tabular}

B Hastanesinin İkinci Basamak testi sonuçlarını gösteren Grafik 5'e bakıldığında, belirgin geometrik uyumsuzluk göze çarpmaktadır. 3, 6, 8, 9 ve 10 hariç diğer rakamlar beklenen değerlerden ciddi sapmalar göstermiştir. 0,02710 olarak hesaplanan MAD değerine göre veri seti Benford yasası ile uyumsuz çıkmıştır.

Grafik 5: B Hastanesi 800 Hesabı 2.Basamak Testi Sonuçları

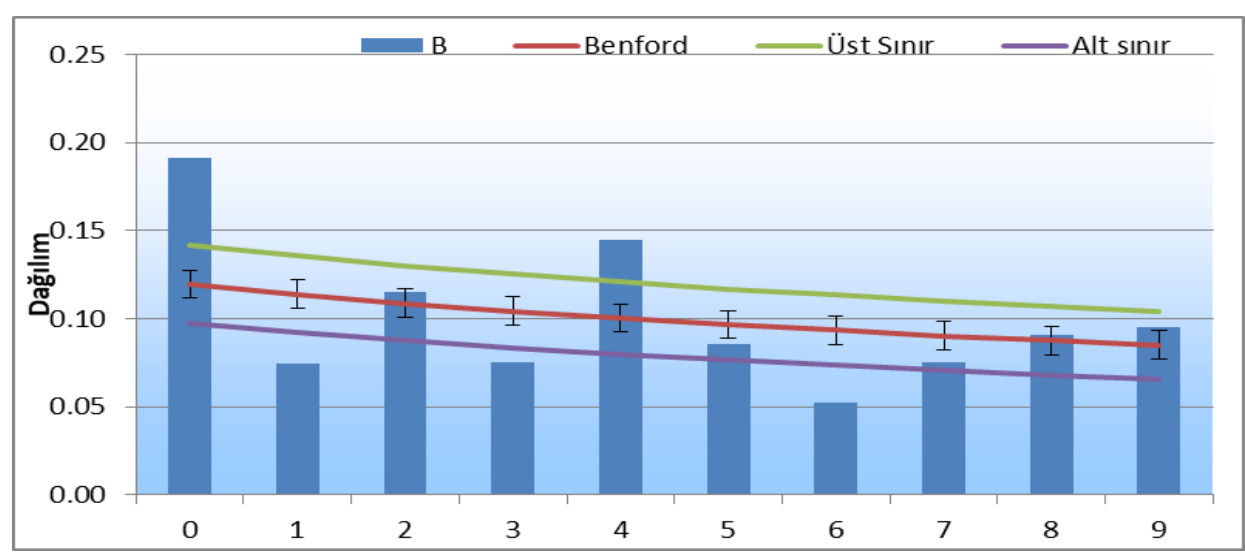

\begin{tabular}{|r|r|r|r|r|r|r|r|r|}
\hline 2.Basamak & \multicolumn{1}{l|}{ Adet } & \multicolumn{1}{l|}{ B } & \multicolumn{1}{l|}{ Benford } & \multicolumn{1}{l|}{ Fark } & Üst Sinır & \multicolumn{1}{l|}{ Alt sınır } & Z Değeri & \\
\hline$\underline{0}$ & 165 & 0,191 & 0,120 & 0,072 & 0,142 & 0,097 & 6,436 & \\
\hline$\underline{1}$ & 64 & 0,074 & 0,114 & 0,040 & 0,136 & 0,092 & 3,610 & \\
\hline$\underline{2}$ & 99 & 0,115 & 0,109 & 0,006 & 0,130 & 0,087 & 0,514 & \\
\hline$\underline{3}$ & 65 & 0,075 & 0,104 & 0,029 & 0,125 & 0,083 & 2,722 & \\
\hline$\underline{4}$ & 125 & 0,145 & 0,100 & 0,045 & 0,121 & 0,080 & 4,312 & \\
\hline$\underline{5}$ & 74 & 0,086 & 0,097 & 0,011 & 0,117 & 0,076 & 1,018 & \\
\hline$\underline{6}$ & 45 & 0,052 & 0,093 & 0,041 & 0,113 & 0,073 & 4,096 & \\
\hline$\underline{7}$ & 65 & 0,075 & 0,090 & 0,015 & 0,110 & 0,071 & 1,471 & \\
\hline$\underline{8}$ & 78 & 0,090 & 0,088 & 0,003 & 0,107 & 0,068 & 0,243 & \\
\hline$\underline{9}$ & 82 & 0,095 & 0,085 & 0,010 & 0,104 & 0,066 & 1,005 & \\
\hline $\mathrm{N}$ & 862 & & MAD & $\mathbf{0 , 0 2 7}$ & & & & \\
\hline
\end{tabular}

\subsection{3. İlk İki Basamak Testi}

A Hastanesinin İlk İki Basamak testi sonuçlarını gösteren Grafik 6'ya bakıldığında 12, 24, 30, ve 60 sayılarında aşırılık 27, 41, 49 ve 53 sayılarında düşüklük göze çarpmaktadır. MAD kritik değerleri tablosunda 0,0022'nin üzeri Uyumsuz olarak kabul edilmektedir. 
Hesaplanan MAD değeri 0,00263 çıkmıştır, ancak sınıra oldukça yakın olduğu da göz önünde bulundurulmalıdır.

Grafik 6: A Hastanesi 800 Hesabı İlk 2 Basamak Testi Sonuçları

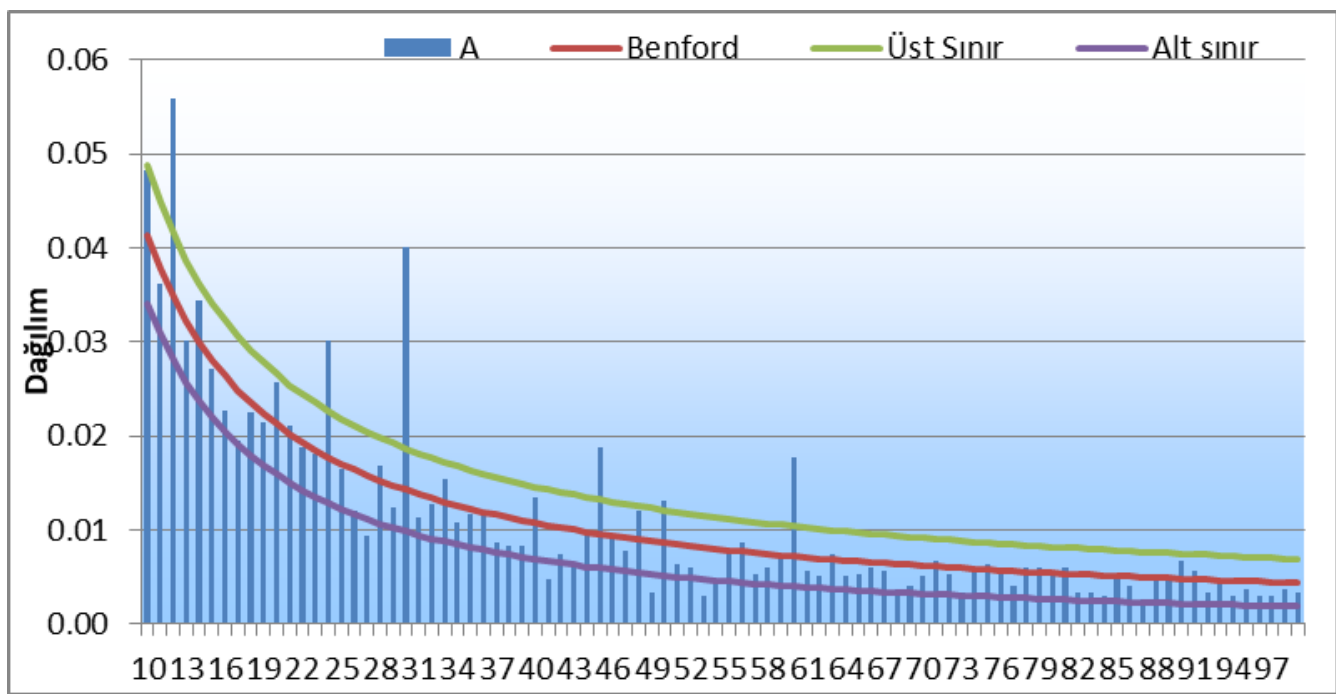

\begin{tabular}{|c|c|c|c|c|c|c|c|}
\hline İlk 2 Basamak & Adet & A & Benford & Fark & Üst Sınır & Alt sinir & Z Değeri \\
\hline$\underline{10}$ & 144 & 0,048 & 0,041 & 0,007 & 0,049 & 0,034 & 1,816 \\
\hline$\underline{11}$ & 108 & 0,036 & 0,038 & 0,002 & 0,045 & 0,031 & 0,427 \\
\hline$\underline{12}$ & 167 & 0,056 & 0,035 & 0,021 & 0,041 & 0,028 & 6,250 \\
\hline$\underline{13}$ & 90 & 0,030 & 0,032 & 0,002 & 0,039 & 0,026 & 0,591 \\
\hline$\underline{14}$ & 103 & 0,034 & 0,030 & 0,004 & 0,036 & 0,024 & 1,388 \\
\hline$\underline{15}$ & 81 & 0,027 & 0,028 & 0,001 & 0,034 & 0,022 & 0,252 \\
\hline$\underline{16}$ & 68 & 0,023 & 0,026 & 0,004 & 0,032 & 0,020 & 1,165 \\
\hline$\underline{17}$ & 58 & 0,019 & 0,025 & 0,005 & 0,031 & 0,019 & 1,845 \\
\hline$\underline{18}$ & 67 & 0,022 & 0,023 & 0,001 & 0,029 & 0,018 & 0,324 \\
\hline$\underline{19}$ & 64 & 0,021 & 0,022 & 0,001 & 0,028 & 0,017 & 0,258 \\
\hline$\underline{20}$ & 77 & 0,026 & 0,021 & 0,005 & 0,027 & 0,016 & 1,672 \\
\hline$\underline{90}$ & 20 & 0,007 & 0,005 & 0,002 & 0,007 & 0,002 & 1,365 \\
\hline$\underline{91}$ & 17 & 0,006 & 0,005 & 0,001 & 0,007 & 0,002 & 0,616 \\
\hline$\underline{92}$ & 10 & 0,003 & 0,005 & 0,001 & 0,007 & 0,002 & 0,946 \\
\hline$\underline{93}$ & 13 & 0,004 & 0,005 & 0,000 & 0,007 & 0,002 & 0,103 \\
\hline$\underline{94}$ & 9 & 0,003 & 0,005 & 0,002 & 0,007 & 0,002 & 1,146 \\
\hline$\underline{95}$ & 11 & 0,004 & 0,005 & 0,001 & 0,007 & 0,002 & 0,569 \\
\hline$\underline{96}$ & 9 & 0,003 & 0,005 & 0,001 & 0,007 & 0,002 & 1,080 \\
\hline$\underline{97}$ & 9 & 0,003 & 0,004 & 0,001 & 0,007 & 0,002 & 1,048 \\
\hline$\underline{98}$ & 11 & 0,004 & 0,004 & 0,001 & 0,007 & 0,002 & 0,463 \\
\hline$\underline{99}$ & 10 & 0,003 & 0,004 & 0,001 & 0,007 & 0,002 & 0,707 \\
\hline $\mathrm{N}$ & 2989 & & MAD & 0,0026 & & & \\
\hline
\end{tabular}


B Hastanesinin ilk iki basamak sonuçları Grafik 7'de gösterilmiştir. Buna göre beklenen dağılımdan sapmalar oldukça belirgindir. Örneğin 30, 60 ve 90 saylarıyla başlayan veriler beklenenden çok fazladır. Hesaplanan MAD değeri 0,0055'tir. En üst uyum sınırı olan 0,0022'den yüksek olan bu değer veri setini uyumsuz olarak nitelendirmektedir.

Grafik 7: B Hastanesi 800 Hesabı İlk 2 Basamak Testi Sonuçları

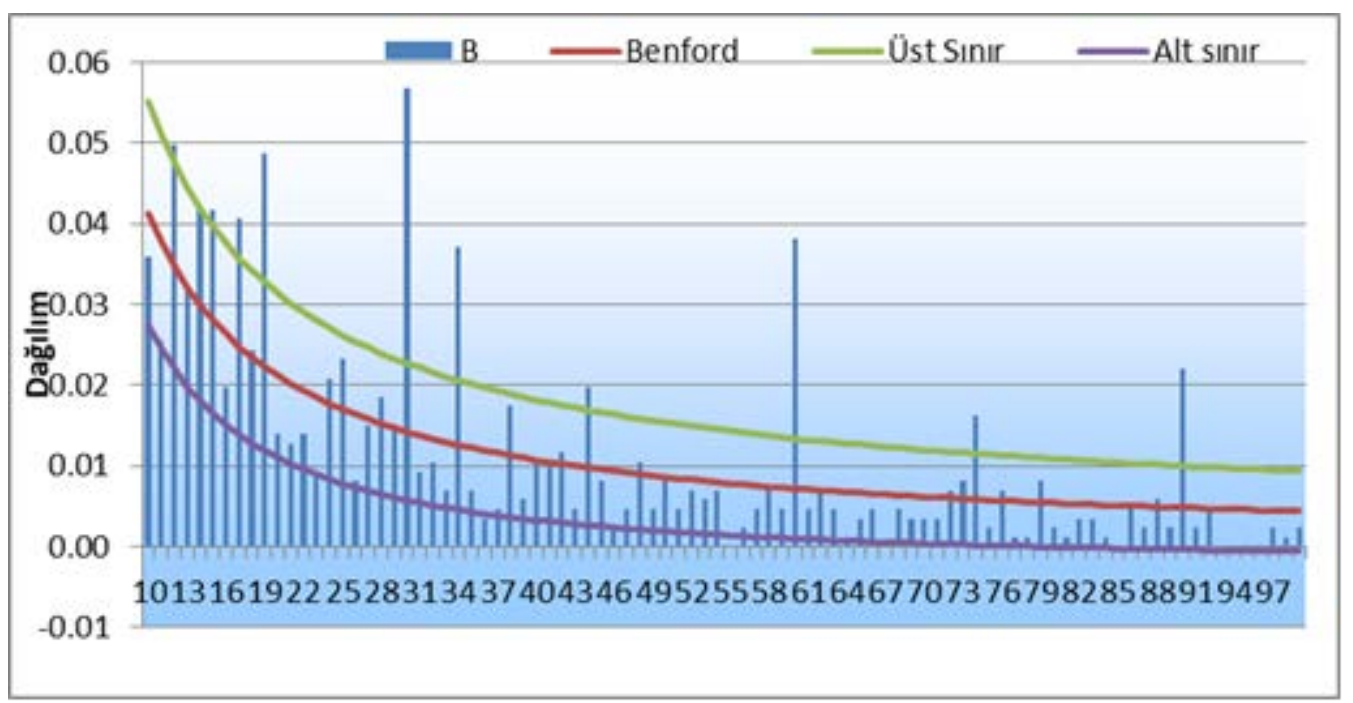

\begin{tabular}{|c|c|c|c|c|c|c|c|}
\hline İlk 2 Basamak & Adet & $\mathbf{B}$ & Benford & Fark & Üst Sınır & Alt sinir & Z Değeri \\
\hline$\underline{10}$ & 31 & 0,036 & 0,041 & 0,005 & 0,055 & 0,028 & 0,715 \\
\hline$\underline{11}$ & 22 & 0,026 & 0,038 & 0,012 & 0,051 & 0,024 & 1,799 \\
\hline$\underline{12}$ & 43 & 0,050 & 0,035 & 0,015 & 0,048 & 0,022 & 2,331 \\
\hline$\underline{13}$ & 28 & 0,032 & 0,032 & 0,000 & 0,045 & 0,020 & $-0,047$ \\
\hline$\underline{14}$ & 36 & 0,042 & 0,030 & 0,012 & 0,042 & 0,018 & 1,932 \\
\hline$\underline{15}$ & 36 & 0,042 & 0,028 & 0,014 & 0,040 & 0,016 & 2,340 \\
\hline$\underline{16}$ & 17 & 0,020 & 0,026 & 0,007 & 0,038 & 0,015 & 1,105 \\
\hline$\underline{17}$ & 35 & 0,041 & 0,025 & 0,016 & 0,036 & 0,014 & 2,868 \\
\hline$\underline{18}$ & 21 & 0,024 & 0,023 & 0,001 & 0,034 & 0,013 & 0,058 \\
\hline$\underline{19}$ & 42 & 0,049 & 0,022 & 0,026 & 0,033 & 0,012 & 5,146 \\
\hline$\underline{20}$ & 12 & 0,014 & 0,021 & 0,007 & 0,031 & 0,011 & 1,363 \\
\hline$\underline{90}$ & 19 & 0,022 & 0,005 & 0,017 & 0,010 & 0,000 & 7,079 \\
\hline$\underline{91}$ & 2 & 0,002 & 0,005 & 0,002 & 0,010 & 0,000 & 0,789 \\
\hline$\underline{92}$ & 4 & 0,005 & 0,005 & 0,000 & 0,010 & 0,000 & $-0,226$ \\
\hline$\underline{93}$ & 0 & 0,000 & 0,005 & 0,005 & 0,010 & 0,000 & 1,755 \\
\hline$\underline{94}$ & 0 & 0,000 & 0,005 & 0,005 & 0,010 & 0,000 & 1,743 \\
\hline$\underline{95}$ & 0 & 0,000 & 0,005 & 0,005 & 0,010 & $-0,001$ & 1,731 \\
\hline$\underline{96}$ & 0 & 0,000 & 0,005 & 0,005 & 0,010 & $-0,001$ & 1,720 \\
\hline$\underline{97}$ & 2 & 0,002 & 0,004 & 0,002 & 0,009 & $-0,001$ & 0,685 \\
\hline$\underline{98}$ & 1 & 0,001 & 0,004 & 0,003 & 0,009 & $-0,001$ & 1,183 \\
\hline$\underline{99}$ & 2 & 0,002 & 0,004 & 0,002 & 0,009 & $-0,001$ & 0,652 \\
\hline $\mathrm{N}$ & 862 & & MAD & 0,0055 & & & \\
\hline
\end{tabular}




\subsection{Bütçe Giderleri Hesabı}

\subsubsection{Birinci Basamak Testi}

A hastanesinin 830 nolu hesabının muavin kayıtlarında 7.489 adet veri bulunmaktadır. Bunlardan 109 tanesi 10'dan küçük olduğundan analize dahil edilmemiştir. Birinci basamak testi sonuçları Grafik 8'de gösterilmektedir. Buna göre 1, 3, 6 ve rakamları uyumsuz görünmektedir. MAD değerine bakıldığında, 0,008 değeri kabul edilebilir uyumlu sayılmaktadir.

Grafik 8: A Hastanesi 830 Hesabı 1.Basamak Testi Sonuçları

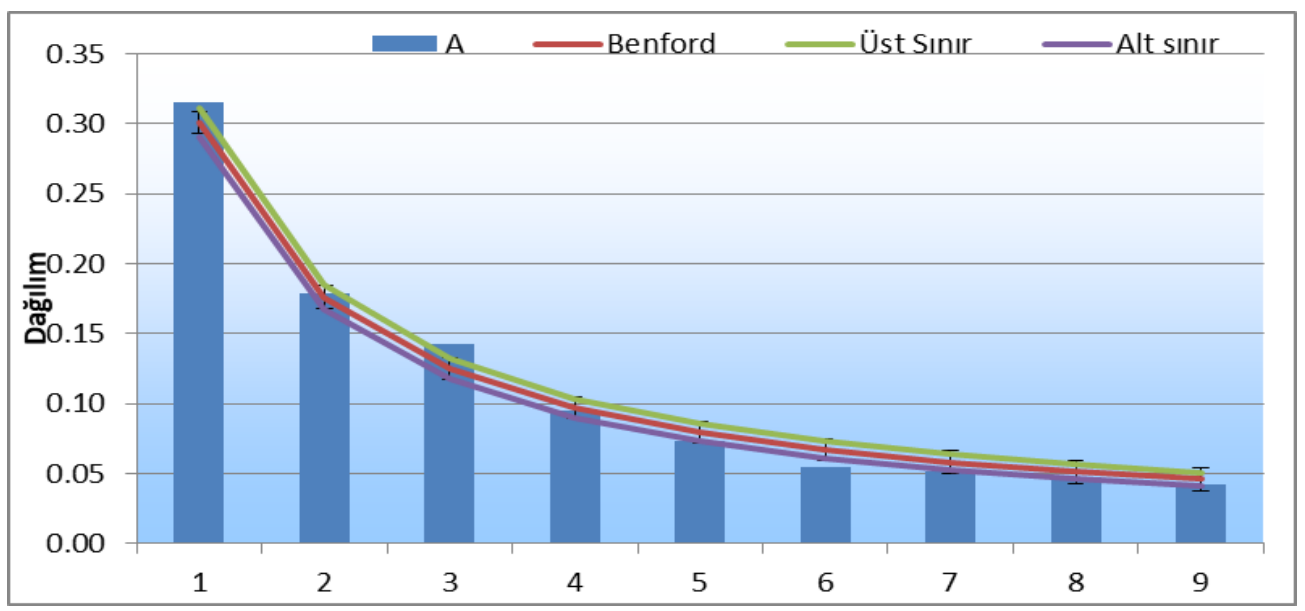

\begin{tabular}{|r|r|r|r|r|r|r|r|}
\hline 1.Basamak & \multicolumn{1}{l|}{ Adet } & \multicolumn{1}{l|}{ A } & \multicolumn{1}{l|}{ Benford } & \multicolumn{1}{l|}{ Fark } & \multicolumn{1}{l|}{ Üst Sınır } & \multicolumn{1}{l|}{ Alt sınır } & \multicolumn{1}{l|}{ Z Değeri } \\
\hline$\underline{1}$ & 2.330 & 0,316 & 0,301 & 0,015 & 0,312 & 0,290 & 2,738 \\
\hline$\underline{2}$ & 1.320 & 0,179 & 0,176 & 0,003 & 0,185 & 0,167 & 0,610 \\
\hline$\underline{3}$ & 1.049 & 0,142 & 0,125 & 0,017 & 0,133 & 0,117 & 4,452 \\
\hline$\underline{4}$ & 698 & 0,095 & 0,097 & 0,002 & 0,104 & 0,090 & 0,657 \\
\hline$\underline{5}$ & 542 & 0,073 & 0,079 & 0,006 & 0,085 & 0,073 & 1,804 \\
\hline$\underline{6}$ & 402 & 0,054 & 0,067 & 0,012 & 0,073 & 0,061 & 4,265 \\
\hline$\underline{7}$ & 380 & 0,051 & 0,058 & 0,007 & 0,063 & 0,053 & 2,365 \\
\hline$\underline{8}$ & 348 & 0,047 & 0,051 & 0,004 & 0,056 & 0,046 & 1,533 \\
\hline$\underline{9}$ & 311 & 0,042 & 0,046 & 0,004 & 0,051 & 0,041 & 1,459 \\
\hline $\mathrm{N}$ & 7.380 & & MAD & $\mathbf{0 , 0 0 8}$ & & & \\
\hline
\end{tabular}

B hastanesinin 830 Bütçe Giderleri Hesap muavininde 1406 adet veri bulunmaktadır. Bunlardan 90 tanesi 10'dan küçük olduğundan analiz dişı bırakılmıştır. Grafik 9'da gösterilen sonuçlara göre ilk basamak dağılımları Benford kanununu izlememektedir. İlk Basamak için hesaplanan MAD değeri 0,01745'tir. Bu değer uyum sınırlarının üzerinde olduğundan Uyumsuz olarak değerlendirilir. 
Grafik 9: B Hastanesi 830 Hesabı 1.Basamak Testi Sonuçları

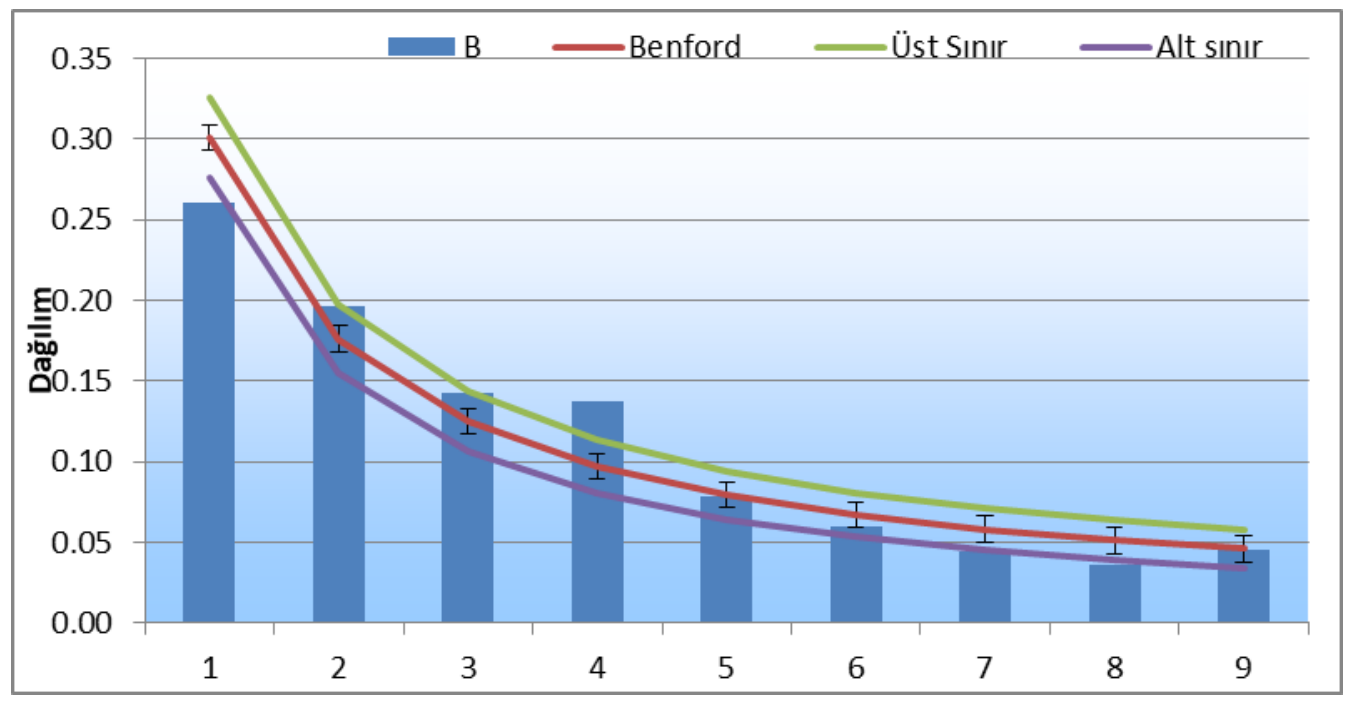

\begin{tabular}{|r|r|r|r|r|r|r|r|}
\hline 1.Basamak & \multicolumn{1}{l|}{ Adet } & \multicolumn{1}{l|}{ B } & \multicolumn{1}{l|}{ Benford } & \multicolumn{1}{l|}{ Fark } & \multicolumn{1}{c|}{ Üst Sınır } & \multicolumn{1}{c|}{ Alt sınır } & Z Değeri \\
\hline$\underline{1}$ & 343 & 0,261 & 0,301 & 0,040 & 0,326 & 0,276 & 3,164 \\
\hline$\underline{2}$ & 259 & 0,197 & 0,176 & 0,021 & 0,197 & 0,155 & 1,937 \\
\hline$\underline{3}$ & 187 & 0,142 & 0,125 & 0,017 & 0,143 & 0,107 & 1,841 \\
\hline$\underline{4}$ & 181 & 0,138 & 0,097 & 0,041 & 0,113 & 0,081 & 4,935 \\
\hline$\underline{5}$ & 103 & 0,078 & 0,079 & 0,001 & 0,094 & 0,064 & 0,072 \\
\hline$\underline{6}$ & 79 & 0,060 & 0,067 & 0,007 & 0,081 & 0,053 & 0,949 \\
\hline$\underline{7}$ & 58 & 0,044 & 0,058 & 0,014 & 0,071 & 0,045 & 2,101 \\
\hline$\underline{8}$ & 47 & 0,036 & 0,051 & 0,015 & 0,063 & 0,039 & 2,480 \\
\hline$\underline{9}$ & 59 & 0,045 & 0,046 & 0,001 & 0,057 & 0,034 & 0,095 \\
\hline $\mathrm{N}$ & 1.316 & & MAD & $\mathbf{0 , 0 1 7}$ & & & \\
\hline
\end{tabular}

\subsection{2. İkinci Basamak Testi}

A Hastanesi ikinci basamak testi sonuçları Grafik 10'da görülmektedir. Z istatistik değerlerine göre sadece 3 ve 8 rakamlarında anlamlı sapmalar mevcuttur. 0,005 olarak hesaplanan MAD değeri dağılımın Benford yasası ile yakın uyumlu olduğu anlamına gelmektedir. 
Grafik 10: A Hastanesi 830 Hesabı 2.Basamak Testi Sonuçları

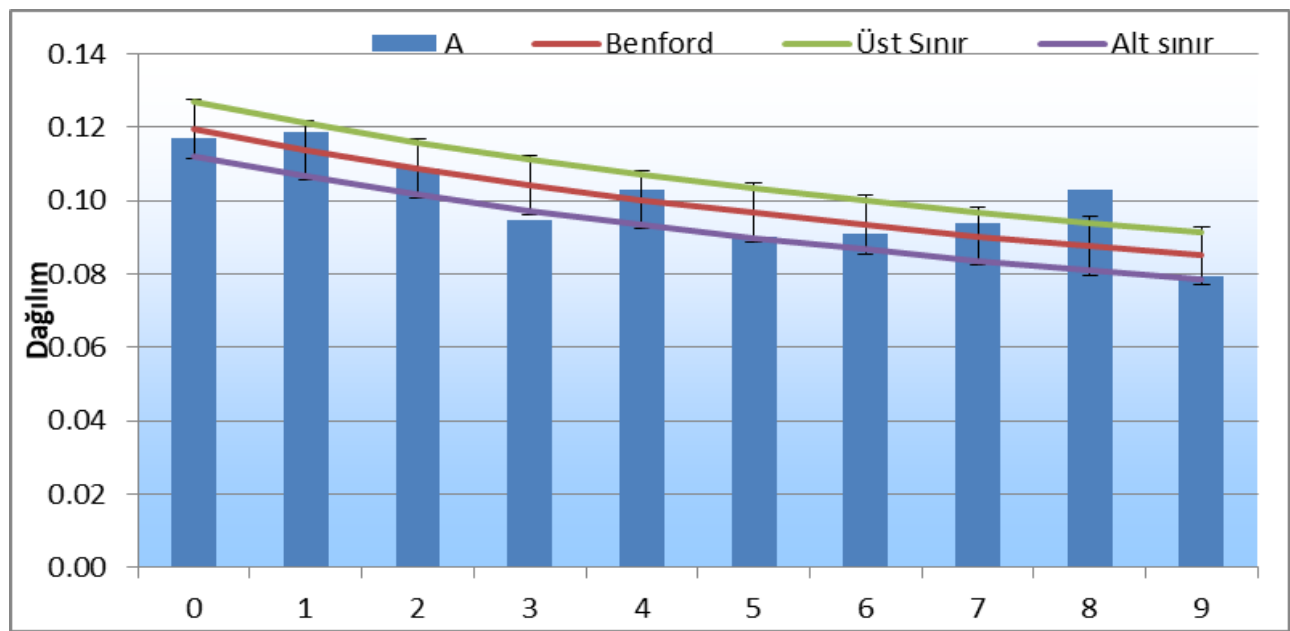

\begin{tabular}{|r|r|r|r|r|r|r|r|}
\hline 2.Basamak & \multicolumn{1}{l|}{ Adet } & \multicolumn{1}{l|}{ A } & \multicolumn{1}{l|}{ Benford } & \multicolumn{1}{l|}{ Fark } & \multicolumn{1}{l|}{ Üst Sınır } & \multicolumn{1}{c|}{ Alt sınır } & Z Değeri \\
\hline$\underline{0}$ & 865 & 0,117 & 0,120 & 0,002 & 0,127 & 0,112 & 0,636 \\
\hline$\underline{1}$ & 877 & 0,119 & 0,114 & 0,005 & 0,121 & 0,107 & 1,319 \\
\hline$\underline{2}$ & 802 & 0,109 & 0,109 & 0,000 & 0,116 & 0,102 & 0,023 \\
\hline$\underline{3}$ & 700 & 0,095 & 0,104 & 0,009 & 0,111 & 0,097 & 2,645 \\
\hline$\underline{4}$ & 761 & 0,103 & 0,100 & 0,003 & 0,107 & 0,093 & 0,784 \\
\hline$\underline{5}$ & 665 & 0,090 & 0,097 & 0,007 & 0,103 & 0,090 & 1,890 \\
\hline$\underline{6}$ & 672 & 0,091 & 0,093 & 0,002 & 0,100 & 0,087 & 0,664 \\
\hline$\underline{7}$ & 692 & 0,094 & 0,090 & 0,003 & 0,097 & 0,084 & 1,003 \\
\hline$\underline{8}$ & 759 & 0,103 & 0,088 & 0,015 & 0,094 & 0,081 & 4,622 \\
\hline$\underline{9}$ & 587 & 0,080 & 0,085 & 0,005 & 0,091 & 0,079 & 1,660 \\
\hline $\mathrm{N}$ & 7.380 & & MAD & $\mathbf{0 , 0 0 5}$ & & & \\
\hline
\end{tabular}

B hastanesinin ikinci basamak sonuçlarıni gösteren Grafik 11'e bakıldığında A hastanesine nazaran daha uyumsuz dağılımlar göze çarpmaktadır. MAD değeri de kritik değerler tablosunun uyumsuzluk sınırında gerçekleşmiştir.

Grafik 11: B Hastanesi 830 Hesabı 2.Basamak Testi Sonuçları

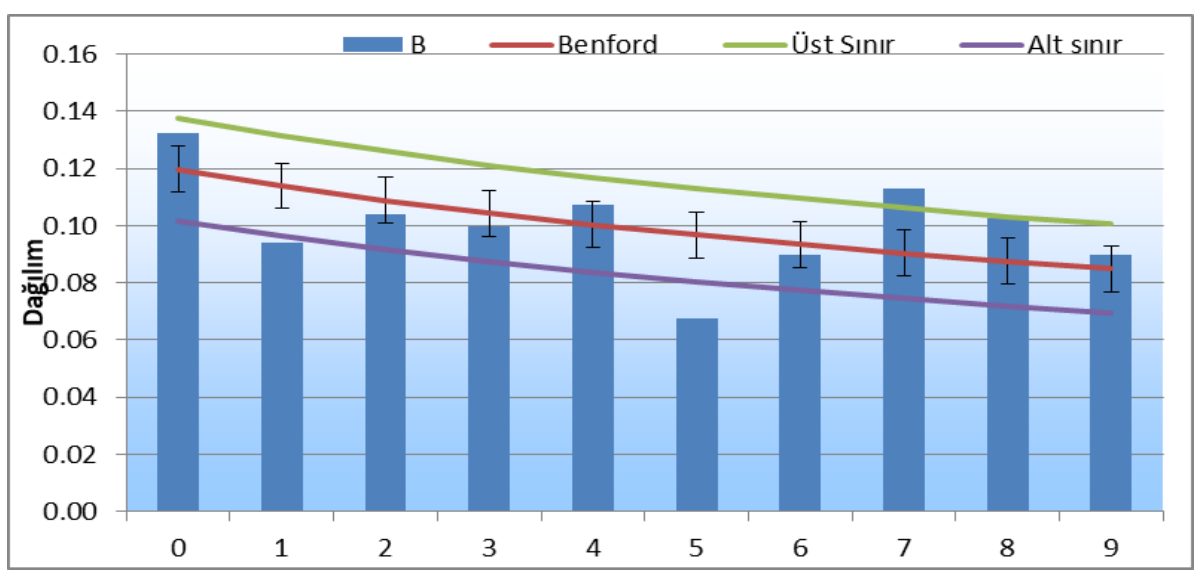




\begin{tabular}{|c|c|c|c|c|c|c|c|}
\hline 2.Basamak & Adet & B & Benford & Fark & Üst Sınır & Alt sinır & Z Değeri \\
\hline$\underline{0}$ & 174 & 0,132 & 0,120 & 0,013 & 0,138 & 0,102 & 1,359 \\
\hline$\underline{1}$ & 124 & 0,094 & 0,114 & 0,020 & 0,131 & 0,096 & 2,202 \\
\hline$\underline{2}$ & 137 & 0,104 & 0,109 & 0,005 & 0,126 & 0,092 & 0,505 \\
\hline$\underline{3}$ & 131 & 0,100 & 0,104 & 0,005 & 0,121 & 0,087 & 0,523 \\
\hline$\underline{4}$ & 141 & 0,107 & 0,100 & 0,007 & 0,117 & 0,084 & 0,779 \\
\hline$\underline{5}$ & 89 & 0,068 & 0,097 & 0,029 & 0,113 & 0,080 & 3,519 \\
\hline$\underline{6}$ & 118 & 0,090 & 0,093 & 0,004 & 0,109 & 0,077 & 0,415 \\
\hline$\underline{7}$ & 149 & 0,113 & 0,090 & 0,023 & 0,106 & 0,074 & 2,846 \\
\hline$\underline{8}$ & 135 & 0,103 & 0,088 & 0,015 & 0,103 & 0,072 & 1,878 \\
\hline$\underline{9}$ & 118 & 0,090 & 0,085 & 0,005 & 0,100 & 0,070 & 0,558 \\
\hline $\mathrm{N}$ & 1.316 & & MAD & 0,012 & & & \\
\hline
\end{tabular}

\subsection{3. İlk iki Basamak Testi}

A hastanesi İlk İki Basamak testi sonuçları Grafik 12'de verilmiştir. MAD değeri 0,00188 olarak hesaplanmıştır. Bu değer Kabul Edilebilir Uyumlu aralığında bulunmaktadır. Nigrini (2011) grafikteki 4-5 pikin normal kabul edilmesi gerektiğini ifade etmektedir.

Grafik 12: A Hastanesi 830 Hesabı İlk 2 Basamak Testi Sonuçları

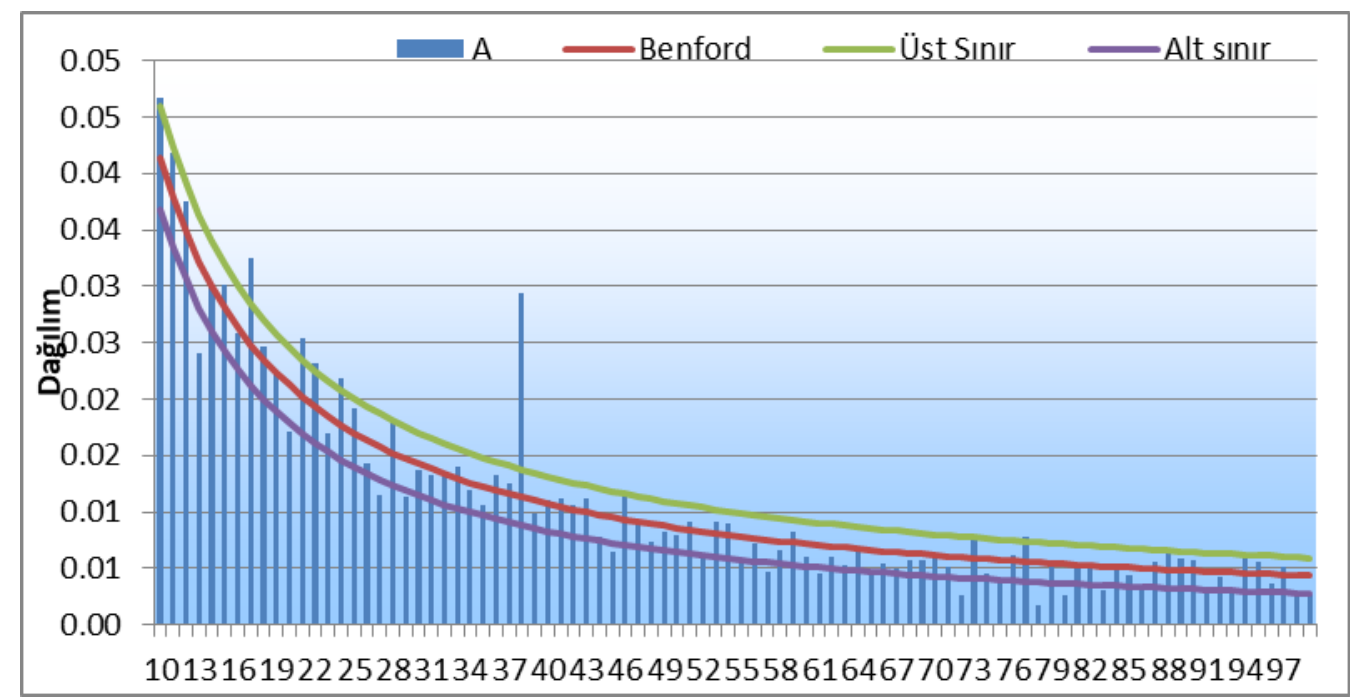




\begin{tabular}{|c|c|c|c|c|c|c|c|}
\hline İlk 2 Basamak & Adet & A & Benford & Fark & Üst Sınır & Alt sinir & Z Değeri \\
\hline$\underline{10}$ & 345 & 0,047 & 0,041 & 0,005 & 0,046 & 0,037 & 2,280 \\
\hline$\underline{11}$ & 309 & 0,042 & 0,038 & 0,004 & 0,042 & 0,033 & 1,808 \\
\hline$\underline{12}$ & 277 & 0,038 & 0,035 & 0,003 & 0,039 & 0,031 & 1,268 \\
\hline$\underline{13}$ & 178 & 0,024 & 0,032 & 0,008 & 0,036 & 0,028 & 3,893 \\
\hline$\underline{14}$ & 221 & 0,030 & 0,030 & 0,000 & 0,034 & 0,026 & $-0,025$ \\
\hline$\underline{15}$ & 222 & 0,030 & 0,028 & 0,002 & 0,032 & 0,024 & 1,033 \\
\hline$\underline{16}$ & 191 & 0,026 & 0,026 & 0,000 & 0,030 & 0,023 & 0,204 \\
\hline$\underline{17}$ & 240 & 0,033 & 0,025 & 0,008 & 0,028 & 0,021 & 4,212 \\
\hline$\underline{18}$ & 182 & 0,025 & 0,023 & 0,001 & 0,027 & 0,020 & 0,631 \\
\hline$\underline{19}$ & 165 & 0,022 & 0,022 & 0,000 & 0,026 & 0,019 & 0,008 \\
\hline$\underline{20}$ & 126 & 0,017 & 0,021 & 0,004 & 0,025 & 0,018 & 2,415 \\
\hline$\underline{90}$ & 42 & 0,006 & 0,005 & 0,001 & 0,006 & 0,003 & 1,025 \\
\hline$\underline{91}$ & 24 & 0,003 & 0,005 & 0,001 & 0,006 & 0,003 & 1,783 \\
\hline$\underline{92}$ & 31 & 0,004 & 0,005 & 0,000 & 0,006 & 0,003 & 0,536 \\
\hline$\underline{93}$ & 23 & 0,003 & 0,005 & 0,002 & 0,006 & 0,003 & 1,845 \\
\hline$\underline{94}$ & 47 & 0,006 & 0,005 & 0,002 & 0,006 & 0,003 & 2,166 \\
\hline$\underline{95}$ & 41 & 0,006 & 0,005 & 0,001 & 0,006 & 0,003 & 1,200 \\
\hline$\underline{96}$ & 27 & 0,004 & 0,005 & 0,001 & 0,006 & 0,003 & 0,994 \\
\hline$\underline{97}$ & 38 & 0,005 & 0,004 & 0,001 & 0,006 & 0,003 & 0,809 \\
\hline$\underline{98}$ & 19 & 0,003 & 0,004 & 0,002 & 0,006 & 0,003 & 2,291 \\
\hline$\underline{99}$ & 19 & 0,003 & 0,004 & 0,002 & 0,006 & 0,003 & 2,245 \\
\hline $\mathrm{N}$ & 7380 & & MAD & 0,002 & & & \\
\hline
\end{tabular}

Grafik 13'te gösterilen B hastanesi ilk iki basamak testi sonuçlarına bakıldığında, beklenen dağılımın altında ve üstünde birçok gerçekleşme noktası göze çarpmaktadır. 0,00333 olarak hesaplanan MAD değeri en üst uyum sınırı olan 0,0022'nin üzerinde olduğundan test sonucu uyumsuz olarak değerlendirilir.

Grafik 13: B Hastanesi 830 Hesabı İlk 2Basamak Testi Sonuçları

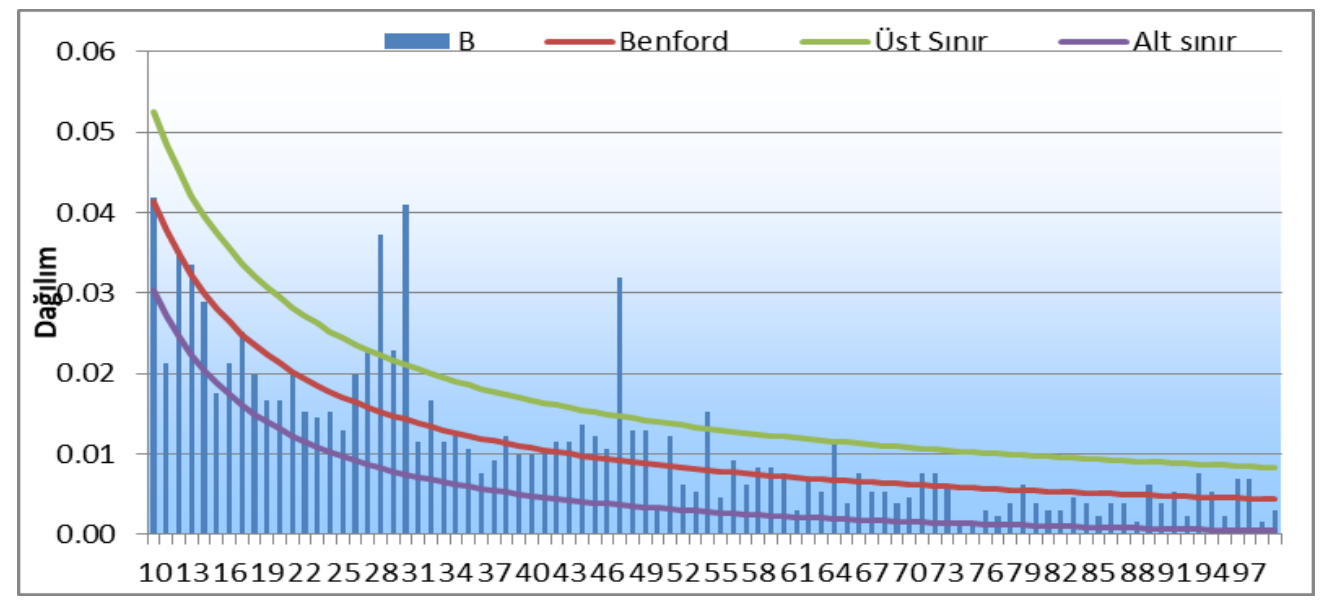




\begin{tabular}{|c|c|c|c|c|c|c|c|}
\hline İlk 2 Basamak & Adet & B & Benford & Fark & Üst Sınır & Alt sınır & Z Değeri \\
\hline$\underline{10}$ & 55 & 0,042 & 0,041 & 0,000 & 0,053 & 0,030 & 0,004 \\
\hline$\underline{11}$ & 28 & 0,021 & 0,038 & 0,017 & 0,048 & 0,027 & 3,069 \\
\hline$\underline{12}$ & 46 & 0,035 & 0,035 & 0,000 & 0,045 & 0,024 & $-0,037$ \\
\hline$\underline{13}$ & 44 & 0,033 & 0,032 & 0,001 & 0,042 & 0,022 & 0,179 \\
\hline$\underline{14}$ & 38 & 0,029 & 0,030 & 0,001 & 0,040 & 0,020 & 0,151 \\
\hline$\underline{15}$ & 23 & 0,017 & 0,028 & 0,011 & 0,037 & 0,019 & 2,236 \\
\hline$\underline{16}$ & 28 & 0,021 & 0,026 & 0,005 & 0,035 & 0,017 & 1,059 \\
\hline$\underline{17}$ & 33 & 0,025 & 0,025 & 0,000 & 0,034 & 0,016 & $-0,030$ \\
\hline$\underline{18}$ & 26 & 0,020 & 0,023 & 0,004 & 0,032 & 0,015 & 0,801 \\
\hline$\underline{19}$ & 22 & 0,017 & 0,022 & 0,006 & 0,031 & 0,014 & 1,273 \\
\hline$\underline{20}$ & 22 & 0,017 & 0,021 & 0,004 & 0,029 & 0,013 & 1,031 \\
\hline$\underline{90}$ & 5 & 0,004 & 0,005 & 0,001 & 0,009 & 0,001 & 0,325 \\
\hline$\underline{91}$ & 7 & 0,005 & 0,005 & 0,001 & 0,009 & 0,001 & 0,102 \\
\hline$\underline{92}$ & 3 & 0,002 & 0,005 & 0,002 & 0,009 & 0,001 & 1,080 \\
\hline$\underline{93}$ & 10 & 0,008 & 0,005 & 0,003 & 0,009 & 0,001 & 1,373 \\
\hline$\underline{94}$ & 7 & 0,005 & 0,005 & 0,001 & 0,009 & 0,001 & 0,184 \\
\hline$\underline{95}$ & 3 & 0,002 & 0,005 & 0,002 & 0,009 & 0,001 & 1,018 \\
\hline$\underline{96}$ & 9 & 0,007 & 0,005 & 0,002 & 0,008 & 0,001 & 1,061 \\
\hline$\underline{97}$ & 9 & 0,007 & 0,004 & 0,002 & 0,008 & 0,000 & 1,092 \\
\hline$\underline{98}$ & 2 & 0,002 & 0,004 & 0,003 & 0,008 & 0,000 & 1,374 \\
\hline$\underline{99}$ & 4 & 0,003 & 0,004 & 0,001 & 0,008 & 0,000 & 0,520 \\
\hline $\mathrm{N}$ & 1316 & & MAD & 0,003 & & & \\
\hline
\end{tabular}

Benford analizi kapsamında yapılan testlerin karşılaştırmalı sonuçları Tablo 2'de verilmiştir. Tabloda $\mathrm{A}$ ve $\mathrm{B}$ hastanelerinin araştırmaya konu muhasebe hesaplarındaki verilerin Benford yasası ile uyum düzeyleri gösterilmektedir. Tabloda her bir test ve veri seti için hesaplanan MAD değerleri, uyum üst sınırına göre değerlendirilmiş ve uyumlu veya uyumsuz olarak derecelendirilmiştir.

Tablo 2: Benford Analizi Karşılaştırmalı Sonuçları

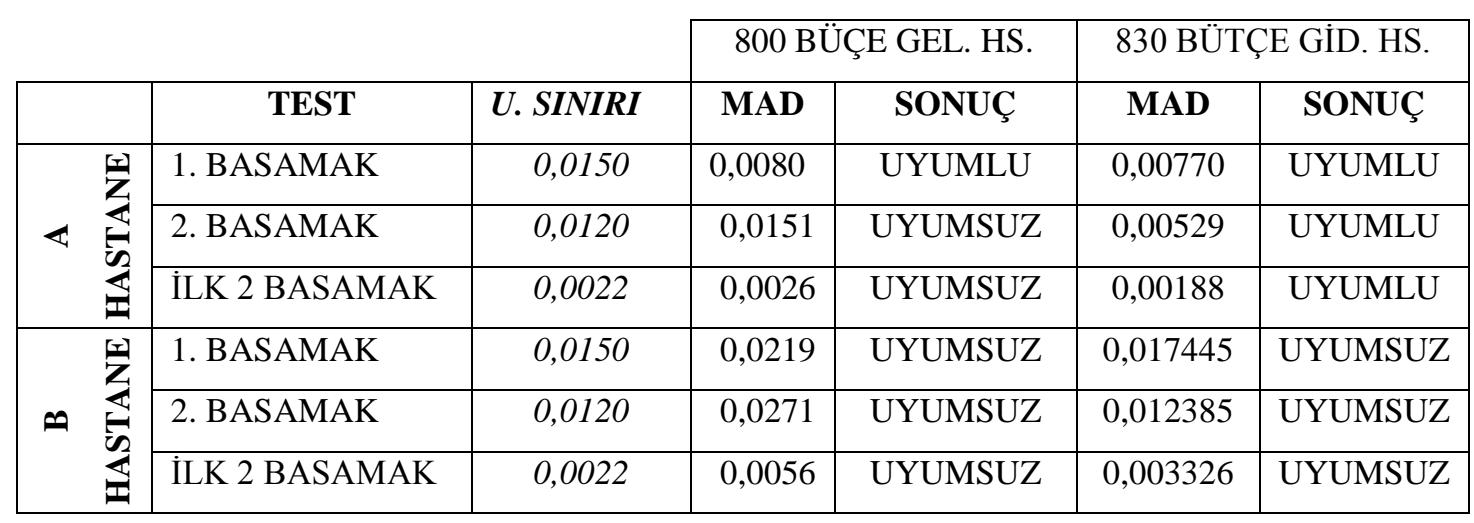


Tablo 2'deki sonuçlara göre A Hastanesinin analiz sonuçları genelde "Uyumlu" çıkmıştır. Uyumsuz çıkan iki sonuç ise uyum sınırına oldukça yakın bulunduğundan genel tabloyu bozmamaktadır. B Hastanesinin analiz sonuçlarının tümü "Uyumsuz" çıkmıştır. Yalnızca bir sonucun uyum sınırına yakın olduğu söylenebilir ancak bu da genel görünümü değiştirmektedir.

\section{SONUÇ}

Çalışmamızda Türkiye'de, aynı ilde faaliyet gösteren iki kamu hastanesinin Bütçe Gelirleri ve Bütçe Giderlerine ait muhasebe hesapları verileri Benford analizine tabi tutulmuştur. Benford Analizi, beklenen dağılımlar ile gerçekleşen dağılımlar arasındaki uyuma göre verilerin orijinalliği hakkında yorum yapmamıza yardımcı olacak sonuçlar verir. Aynı sektör ve aynı ilde faaliyet gösteren iki kamu hastanesinin sonuçlarından birinin diğerine göre belirgin şekilde farklı çıkması verilerin orijinalliğinin bozulmuş olabileceği sinyali olarak değerlendirilebilir. Denetçi denetim yapılacak hastane olarak B Hastanesini seçmeli ve derinlemesine denetim tekniklerini uygulamalıdır. Ayrıca test sonuçlarında görülen belirgin aşırılıklara sahip veriler incelenerek sapma nedenleri hakkında ipuçları sağlanabilir.

Uygulanan Benford analizi verilerin anormallik içerdiği hakkında bir sinyal verir ancak bu sinyallerin gerçekten hile işareti olup olmadı̆̆ derinlemesine denetim sonucu saptanabilir. Yöntemin en büyük faydası araştırma evreninin seçiminde kullanılabilmesidir. Denetçi büyük denetim evreni içerisinde derinlemesine inceleme için seçeceği riskli firmaları bu analiz yardımıyla belirleyebilir. Veri setlerinin çoğunda Benford kanunu ile uyum bulunması, az sayıdaki uyumsuz verilerin anormal olabileceğini destekleyen başka bir unsurdur. İleride yapılacak çalışmalarda Benford analizinde bulunan diğer testler ve farklı muhasebe verileri uygulanarak araştırma genişletilebilir. Ayrıca literatürde yer alan kritik değerler sektörel veya bölgesel koşullar altında yeniden belirlenebilir.

\section{KAYNAKLAR}

Akkaş, Mustafa (2007). “Denetimde Benford Kanunu'nun Uygulanması”, Gazi Üniversitesi İktisadi ve İdari Bilimler Fakültesi Dergisi, 9(1), ss.191 - 206

Alagöz, Ali ve AY, Mustafa (2001), "Muhasebe Denetiminde Benford Kanunu Temelli Dijital Analiz”, Selçuk Üniversitesi Sosyal ve Ekonomik Araştırmalar Dergisi, 4, ss.5976

Benford, Frank (1938). "The Law of Anomalous Numbers, Proceedings of the American Philosophical Society”, 78(4), pp.551-572

Boztepe, Engin (2013). "Benford Kanunu ve Muhasebe Denetiminde Kullanılabilirliğii”, EUL Journal of Social Sciences, IV(I), ss.73-83

Carslaw, Charles (1988). “Anomolies in Income Numbers: Evidence of Goal Oriented Behavior”, The Accounting Review, 63(2), pp.321-327

Çakır, Süleyman (2004). "Muhasebe hilelerinin Tespitinde İstatistiksel Yöntemler (Benford Yönteminin İrdelenmesi)”, Dokuz Eylül Üni., Sos. Bil., Enstitüsü, İzmir 
Çalış, Yıldırım E., Keleş Emrah, Engin Ahmet (2015). "Hilenin Ortaya Çıkartılmasında Bilgi Teknolojilerinin Önemi ve Bir Uygulama”, Muhasebe ve Finansman Dergisi, ss.93108

Demir, Mahmut (2014). “Benford Yasası Ve Hile Denetiminde Kullanılması”, İstanbul Ticaret Üni., Sosyal Bilimler Enstitüsü, İstanbul

Drake, Philip ve Nıgrını, Mark (2000). “Computer Assisted Analytical Procedures Using Benford's Law”, Journal of Accounting Education, 18, pp.127-146

Durtsch1, Cindy. ve Pacin1, C. (2004). “The Effective Use of Benford's Law to Assist in Detecting Fraud in Accounting Data”, Journal of Forensic Accounting, V, pp.17-34

Erdoğan, Mustafa vd. (2014). "Muhasebe Hilelerinin Denetiminde Benford Yasası”, Ankara: Gazi Kitabevi

Hill, T.Philip (1999). “The Difficulty of Faking Data”, Chance, 12(3), pp.27-31

Hill T.Philip. (1998). “The First Digit Phenomenon”, American Scientist, 86(4), pp.358-363

Kocameşe, Mustafa (2006). "Benford Kanunu Ve Vergi Denetiminde Kullanılabilirliğinin İncelenmesi”, Marmara Üniversitesi, Sosyal Bilimler Enstitüsü, İstanbul

Newcomb, Simon (1881). "Note on the Frequency of Use of the Different Digits in Natural Numbers”, American Journal of Mathematics, 4(1), pp.39-40

Nigrını J.Mark ve Mittermaier J. (1997). “The Use of Benford's Law as an Aid in Analytical Procedures”, Atjditing:A Joumal of Practice \& Theory, 16(2), pp.52-57

Nigrını, J. Mark (2012), “Benford’s Law Applications for Forensic Accounting, Auduting and Fraud Dedection”, New Jersey: John Wilwy\&Sons

Nigrını, J.Mark (1996). “A Taxpayer Complience Application of Benfords Law”, The Journal of the American Taxation Association, 18, pp.72-90

Özdemir, Muhammet (2014). "Muhasebe Denetimde Benford Kanunu ve Ölçekten Bağımsızlık Yönteminin sınanmasına Yönelik Bir İnceleme”, İstanbul Üniversitesi, Sosyal Bilimler Enstitüsü, İstanbul

Özer, Gökhan ve Babacan, Burak (2013). “Benford’s Law and Digital Analysis Application on Turkish Banking Sector”, Business and Economics Research Journal, 4(1), 29-41

Thomas, J.K. (1989) Unusual Patterns in Reported Earnings, The Accounting Review, Vol. 64, No. 4 (Oct., 1989), pp. Pp.773-787

Uzuner, Mustafa (2014, Ocak). Benford Yasasının Borsa İstanbul'da İşlem Gören Bankaların Konsolide Bilançolarına Uygulanması, Finansal Araştırmalar ve Çalışmalar Dergisi, 10 , ss.73-82 
Yanık, Ramazan- Samancı Tuna (2013). "Benford Kanunu ve Muhasebe Verilerinde Uygulanmasına Ait Kamu Sektöründe Bir Uygulama1, Atatürk Üniversitesi Sosyal Bilimler Enstitüsü Dergisi, 17(1), ss.335-348 
